\title{
IMPLEMENTATION ANALYSIS OF THE OCCUPATIONAL AND ENVIRONMENTAL SAFETY AND HEALTH MANAGEMENT SYSTEM AT LABORATORY OF UNIVERSITAS INDONESIA
}

\author{
Puteri Salsabila'), Mila Tejamaya²) \\ ${ }^{1)}$ Master of Occupational Health and Safety Program, Faculty of Public Health, Universitas \\ Indonesia \\ 2)Occupational Health and Safety Program Department, Faculty of Public Health, Universitas \\ Indonesia
}

\begin{abstract}
Background: The laboratory is important to conduct the experiments, investigations, and observations of various fields of scientific study. Chemical, physical, biological, and other potential hazards are inseparable with laboratory activities. However, potential hazards are avoidable with risk management through the implementation of the laboratory occupational health and safety management system. This study aimed to investigate the implementation of laboratory occupational health and safety management system aspects at the laboratory of Universitas Indonesia.

Subjects and Method: This was a descriptive study conducted at the laboratory of Universitas Indonesia in 2020. The study informants were head and laboratorians. The study variables were 14 aspects of the implementation of occupational and environmental safety, with a total of 156 checklists. Universitas Indonesia developed the questions in the checklist in the form of closed questions. The data were analyzed by gap analysis and reported descriptively.
\end{abstract}

Results: Laboratories at Universitas Indonesia implemented most of the occupational and environmental safety aspects. The gap analysis showed that there was a need for improvements in the implementation of some aspects, particularly operational control, inspection, and management review.

Conclusion: Some aspect implementations still need to be improved, mainly in operational control, inspection, and management review.

Keywords: Occupational and environmental safety, inspection, laboratory, Universitas Indonesia

\section{Correspondence:}

Mila Tejamaya. Occupational Health and Safety Program Department, Faculty of Public Health, Universitas Indonesia, Depok, West Java, 16424. Email: mila.tejamaya@gmail.com.

Mobile: +628111810100

The $7^{\text {th }}$ International Conference on Public Health Solo, Indonesia, November 18-19, 2020|339 https://doi.org/10.26911/the7thicph.04.24 